\title{
"Compensatory" uniparental disomy of chromosome 21 in two cases
}

Oliver Bartsch, Michael B Petersen, Isabell Stuhlmann, Günther Mau, Merete Frantzen, Eberhard Schwinger, Stylianos E Antonarakis, Margareta Mikkelsen

\begin{abstract}
Two cases of growth failure, microcephaly, facial dysmorphism, muscular hypertonia, and severe psychomotor retardation are described. At birth, both cases had cytogenetic mosaicism in lymphocytes and skin fibroblasts, in case 1 ring chromosome 21 and monosomy 21 and in case 2 , deletion of chromosome 21 and monosomy 21. At a later age the lymphocyte karyotype changed almost completely to $46, \mathrm{XX}$, but the fibroblast karyotype remained as before. DNA polymorphism analysis described elsewhere indicated that the $46, X X$ lymphocytes contained two identical chromosomes 21 (isodisomy), in case 1 inherited from the father and in case 2 from the mother. The isodisomy was the result of duplication of a chromosome in mitosis after the loss of the homologous abnormal chromosome ("compensatory isodisomy"). We report here that this cytogenetic mechanism can result in false normal cytogenetic findings. The phenotypes were attributed to the cells with monosomy 21 in case 1 and to the deletion and monosomy of chromosome 21 in case 2 .
\end{abstract}

( $($ Med Genet 1994;31:534-540)

Recently, a new mechanism leading to uniparental disomy (UPD) was established in two independent cases. ${ }^{1}$ Both persons had abnormalities of chromosome 21 at birth but blood cells with a normal karyotype predominated later in life and the abnormal cells disappeared. Uniparental isodisomy was found in the normal cells. The UPD in these persons was the result of duplication of a chromosome in mitosis after the loss of the homologous abnormal chromosome. It was present only in lymphocytes. The duplicated chromosome 21 was inherited from the father in one case and from the mother in the other. The duplication was seen as a mechanism for cell survival which provided a selective advantage for the cell population with the normal number of chromosomes 21 , and was called "compensatory" isodisomy. We report here the phenotypes of the two persons and the possible significance of the different cell lines.

\section{Case reports}

CASE 1

The proband, a female, was the first child of a healthy, unrelated couple from India. She was born to a 26 year old mother and a 25 year old father in June 1988. There is a normal younger brother.

The pregnancy was normal. After prolonged labour and cardiac decelerations, the child was born by breech delivery. The Apgar score was 4 at one minute. Following stimulation and bag and mask ventilation it improved to 6,9 , and 10 after five, 10 , and 20 minutes. Estimated gestational age was 37 weeks (Dubowitz score). Weight was $1700 \mathrm{~g}$, length $43 \mathrm{~cm}$, and head circumference $29.5 \mathrm{~cm}$. The facies was abnormal with malformed, large, low set ears, downward slanting palpebral fissures, mild telecanthus, a broad nasal bridge, divergent strabismus, a cleft lip, and micrognathia (figs 1 and 2). There was a short neck, an umbilical hernia, and flexed joints (fig 1). A 2/6 systolic heart murmur was heard in the second left parasternal space. Echocardiography (ECG) and $x$ rays of the chest indicated a patent ductus arteriosus without haemodynamic significance. Muscle tone was increased and asymmetrical. The cry was high pitched. On cranial sonography, the lateral ventricles were moderately enlarged.

At 2 months the child was discharged from hospital. Recurrent urinary tract infections have occurred since then, with no anomalies seen on sonography. At 7 months the cleft lip was repaired and the divergent strabismus and dysplasia of the left hip (sonographic stage Graf IIB) were noted. The hydrocephalus had become more marked. At 16 months the child had febrile otitis. A convulsive disorder became apparent and was treated with primidone. At 23 months height was $75 \mathrm{~cm}$ (-3.5 SD), weight $8100 \mathrm{~g}(-3 \mathrm{SD})$, and head circumference $42 \mathrm{~cm}$ $(-4 \mathrm{SD})$.

The child was last seen at 4 years 1 month. There were frequent upper respiratory tract infections, episodes of fever of unknown origin up to $40^{\circ} \mathrm{C}$, and seizures every week. EEG findings included marked hypersynchronous activity with focal and generalised spike waves and sharp slow waves. Vigabatrin was added to the drug treatment. ECG and radiological findings showed dextroversion of the heart. The heart murmur had disappeared. Developmental age was tested with the following results: body control 6-8 months (sits, stands with support, but does not crawl or roll, and uses unphysiological movement patterns); acoustic perception 8-10 months (reacts to scolding, stops crying when spoken to, no head turning towards noises, no understanding of words); language skills 10-15 months (eats solid foods easily, produces sounds, and uses 

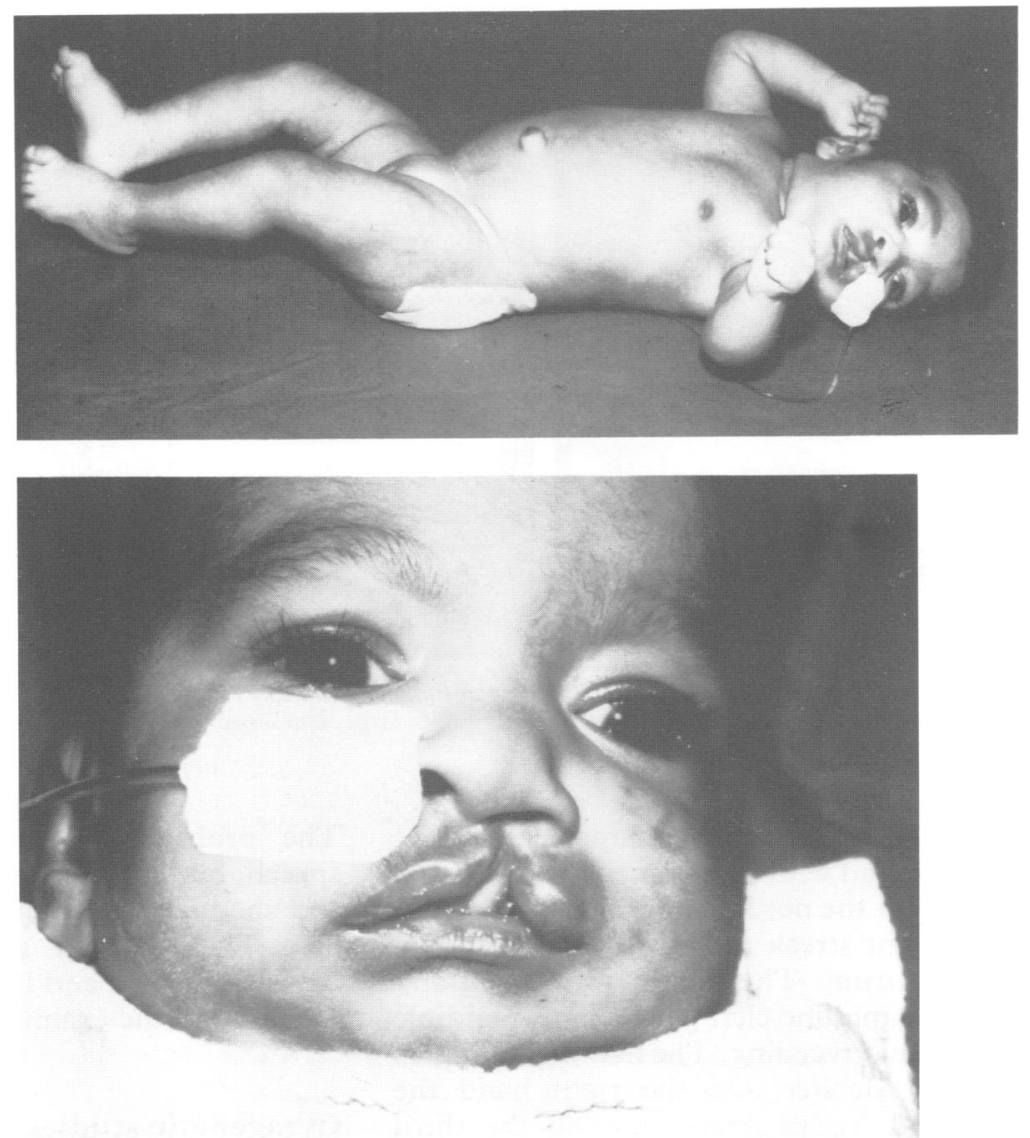

them to communicate her wishes); fine motor skills and visual perception 12-18 months (takes off socks, finds hidden objects, looks at herself in the mirror). The developmental quotient was roughly 25 .

Standard laboratory investigations showed borderline thrombopenia from the neonatal period with platelet counts of 135000-161000/ $\mu l$ (normal range, $150000-400000 / \mu \mathrm{l}$ ), and of $52000-89000 / \mu \mathrm{l}$ during the infection at the age of 16 months. Leucocyte and erythrocyte counts, electrolytes, creatinine, glucose, GGT, GOT, GPT, total serum protein, and immunoglobulin levels were normal except for one reduced IgG level of $2.9 \mathrm{~g} / 1$ (normal range 5$10.8 \mathrm{~g} / \mathrm{l}$ ) during an infection at the age of 2 years 8 months.

CASE 2

The proband, a female, was described in a case report in $1974 .^{2}$ She was born in April 1973 as the second child of unrelated, healthy parents. There was an older healthy sister. The father was 36 and the mother 31 years of age at the birth of the proband. The pregnancy was normal.

The child was born one week before term. Weight was $1650 \mathrm{~g}$, length $41 \mathrm{~cm}$, and head circumference $29 \mathrm{~cm}$. Apgar score was 2 at one minute and 4 at two minutes. Physical examination showed a premature girl with a peculiar appearance (fig 3). The face was asymmetrical. The right external ear was rudimentary and without an external meatus. The left external ear was large and low set. Tomography of the ears showed no development of the inner ear on the right side. The left side was normal except for an abnormal orientation of the labyrinth. There was an antimongoloid slant of 

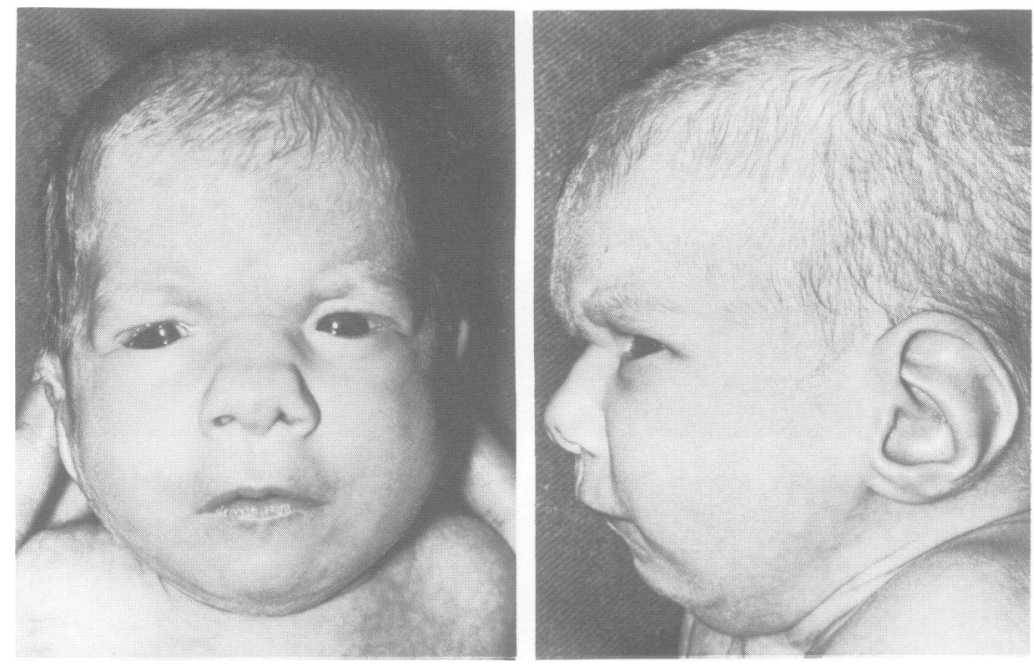

Figure 3 Case 2 at 6 weeks of age. (Left) note antimongoloid slants,

blepharochalasia, and broad nasal bridge. (Right) note large, low set ear and receding chin.

the eyes and bilateral blepharochalasia. The nose was broad with a prominent nasal bridge. On the tip of the nose there was a dimple from which a light streak ran downwards centrally to the philtrum. The mouth was broad and there was a midline cleft palate. The mandible was small and receding. The hands and fingers were very slender. On the right hand the second and fourth finger overlaid the third finger. The first finger of both hands was adducted. The left foot was in calcaneovalgus position and the right foot was inverted. The nails of all fingers and toes were rudimentary. A rough systolic murmur was heard to the left of the sternum. Skeletal radiology showed 13 ribs on the left and hemivertebrae of the tenth and eleventh thoracic vertebrae.

The proband has been seen every second year. She has always lived at home.

Growth has been severely retarded. At the age of 6 years 5 months weight was $10 \mathrm{~kg}$, height $97 \mathrm{~cm}$, and head circumference $43 \mathrm{~cm}$. At 9 years 10 months weight was $14.5 \mathrm{~kg}$ and height $115 \mathrm{~cm}$. At 19 years 9 months weight was $22.5 \mathrm{~kg}$, height $132.5 \mathrm{~cm}$, and head circumference $47.5 \mathrm{~cm}$.

When the girl was 5 years old she walked without support and said a few words, difficult to understand. At the age of 7 years 8 months she was psychologically tested. Cattell's test for infants showed a developmental age of 28 months, that is, a developmental quotient of 30. At 9 years the girl was toilet trained. At 10 years she had surgical elongation of the Achilles' tendons of both feet.

The proband was last seen at the age of 19 years 9 months (figs 4 to 8 ). The hands and fingers were very long and slender. On the left foot the big toe was lying over the other toes in a horizontal position. On the right foot the big toe was lying under the other toes. There was a severe progressive scoliosis and she wore a corset. Vision was normal. The left ear was functioning with a hearing aid, but there was no hearing in the right ear. There was no heart murmur. Lung function was decreased because of the severe scoliosis. Mobility of all joints was reduced. The gait was unsteady.
The proband had very little recognisable speech, but had mastered some sign language, and she understood most of what was said to her. There was a good social interaction between the girl and her parents and between the girl and the examiners.

\section{Cytogenetic studies \\ CASE 1}

Chromosome analysis of 50 cultured lymphocytes and 81 skin fibroblasts with GTG and QFQ banding at the age of 1 month showed cytogenetic moscaisim of ring chromosome 21 $(46, \mathrm{XX},-21,+\mathrm{r}(21)$, or for simplicity 46, $r(21)$ ) and monosomy 21 . At the age of 13 months, a follow up study on 50 lymphocytes

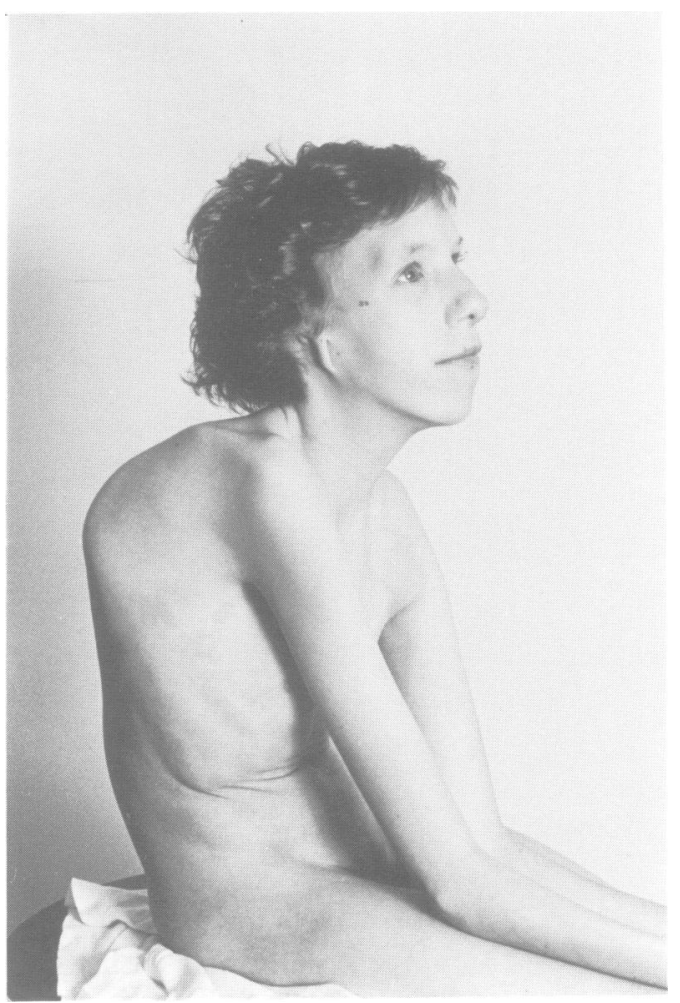

Figure 4 Case 2 at 14 years 8 months. Note rudimentary ear, receding chin, and severe scoliosis. 


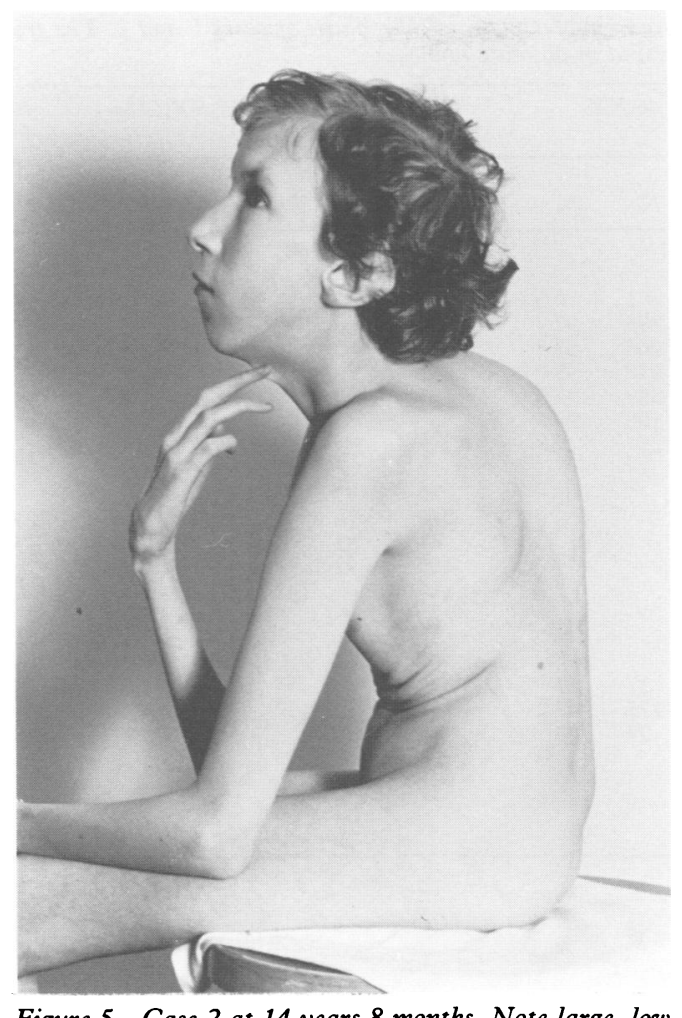

Figure 5 Case 2 at 14 years 8 months. Note large, low set, rotated ear, receding chin, long slender hand and fingers, and severe scoliosis.

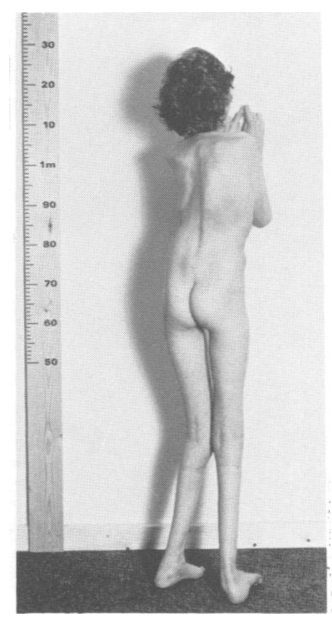

Figure 6 Case 2 at 14 years 8 months. Note very thin build, scoliosis, and abnormal position of feet.

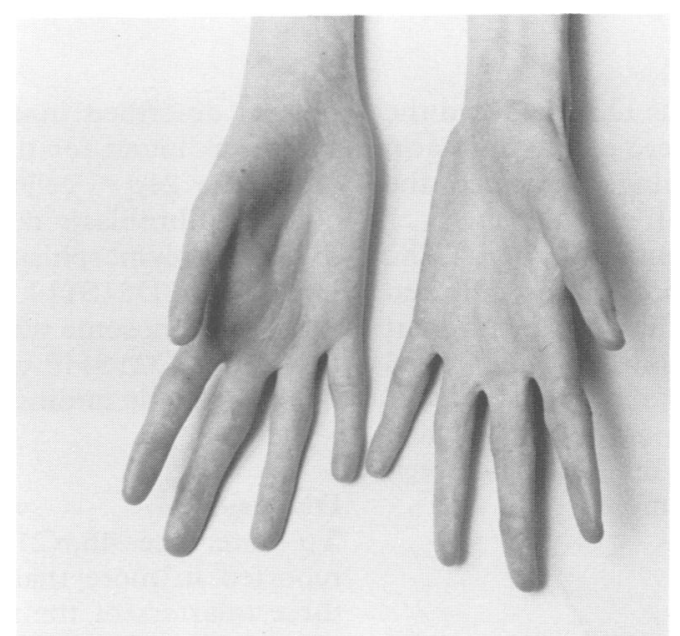

Figure 7 Case 2 aged 14 years 8 months. Note long slender hand and fingers.

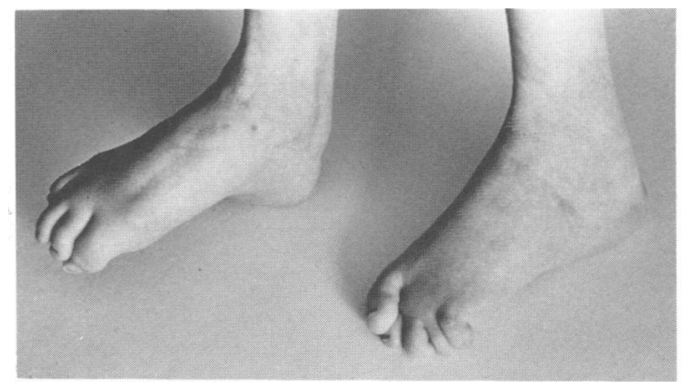

Figure 8 Case 2 aged 14 years 8 months. Note abnormal position of toes.

indicated a 46,XX karyotype. On this finding the chromosome preparations were examined in more detail. The $46, \mathrm{XX}$ karyotype was present in one out of $204(0.5 \%)$ lymphocytes from the age of 1 month and in 293 out of 300 $(97 \cdot 7 \%)$ lymphocytes from the age of 13 months, but not in fibroblasts at either age (table 1). Using fluorescence in situ hybridisation $^{3}$ with chromosome $21 / 13$ alphoid DNA probe $\mathrm{L} 1.26,{ }^{4}$ the two chromosomes 21 from the $46, \mathrm{XX}$ cells appeared identical with respect to the pericentric region and the satellites on the short arms. There were no satellite associations between the $r(21)$ and the acrocentric chromosomes. Single sized rings were smaller than normal chromosomes 21 (fig 9). A minority of the ring chromosomes 21 were double in size and dicentric, with the two centromeres located on opposite sides of the ring. Later cytogenetic studies showed the same results as at 13 months. The parents had normal karyotypes.

\section{CASE 2}

At birth, the proband had a mosaic karyotype of partial deletion of the long arm of chromosome 21 (del(21)(q22.1 $\rightarrow$ qter) or for simplicity $21 \mathrm{q}^{-}$) and monosomy 21 in blood lymphocytes and skin fibroblasts. ${ }^{2}$ At the age of 12 years, the monosomy 21 cell line had disappeared in lymphocytes, the number of cells with $21 \mathrm{q}$ - had greatly decreased, and the majority of cells had two normal chromosomes 21 . In contrast, the fibroblast karyotype at all ages showed the $21 \mathrm{q}-$ deletion. In the $46, \mathrm{XX}$ cell line the satellites on the short arms of chromosomes 21 were different (the short arm of one chromosome was identical to that of the $21 \mathrm{q}$ - chromosome; the short arm of the other was identical to chromosome 21 in the monosomic cell line). The parental karyotypes were normal. Cell lines from the proband have been established.

\section{DNA studies}

Both cases are described in detail by Petersen et al. ${ }^{1}$ Probability of non-paternity was less than $10^{-5}$.

\section{CASE 1}

The 46,XX cells were studied using blood taken at the age of 23 months and 17 different DNA polymorphisms spanning the interval D21S215 (21 - GT14) to COL6A1 (the closest 
Table 1 Cytogenetic findings from lymphocytes and fibroblasts of cases 1 and 2. The frequencies of the different cell lines are indicated as percentages and in absolute numbers

\begin{tabular}{|c|c|c|c|c|c|c|c|c|c|c|c|}
\hline & \multirow{2}{*}{$\begin{array}{l}\text { No of } \\
\text { cells } \\
\text { examined }\end{array}$} & \multicolumn{2}{|c|}{$46, X X$} & \multicolumn{2}{|c|}{$\begin{array}{l}46, X X, r(21) \\
\text { single ring }\end{array}$} & \multicolumn{2}{|c|}{$46, X X,(21 q-)$} & \multicolumn{2}{|c|}{$\begin{array}{l}46, X X, r(21) \\
\text { double ring }\end{array}$} & \multicolumn{2}{|c|}{$45, X X,-21$} \\
\hline & & No & $\%$ & No & $\%$ & No & $\%$ & No & $\%$ & No & $\%$ \\
\hline $\begin{array}{l}\text { Case } 1 \\
\text { Lymphocytes } \\
1 \text { month } \\
13 \text { months } \\
15 \text { months } \\
23 \text { months } \\
30 \text { months } \\
49 \text { months }\end{array}$ & $\begin{array}{l}204 \\
300 \\
300 \\
250 \\
400 \\
200\end{array}$ & $\begin{array}{r}1 \\
293 \\
263 \\
238 \\
389 \\
198\end{array}$ & $\begin{array}{r}0 \cdot 5 \\
97 \cdot 7 \\
87 \cdot 7 \\
95 \cdot 2 \\
97 \cdot 3 \\
99\end{array}$ & $\begin{array}{r}97 \\
2 \\
11 \\
2 \\
3\end{array}$ & $\begin{array}{r}47.5 \\
0.7 \\
3.7 \\
\\
0 \cdot 8 \\
0 \\
0.7\end{array}$ & & & $\begin{array}{l}2 \\
1\end{array}$ & $\begin{array}{l}1^{1} 0 \cdot 3 \\
0 \\
0 \\
0 \\
0\end{array}$ & $\begin{array}{r}104 \\
4 \\
26 \\
10 \\
8 \\
2\end{array}$ & $\begin{array}{l}51 \\
1 \cdot 3 \\
8 \cdot 6 \\
4 \\
2 \\
1\end{array}$ \\
\hline $\begin{array}{l}\text { Fibroblasts } \\
1 \text { month } \\
13 \text { months } \\
30 \text { months } \\
49 \text { months }\end{array}$ & $\begin{array}{r}81 \\
358 \\
100 \\
200\end{array}$ & & $\begin{array}{l}0 \\
0 \\
0 \\
0\end{array}$ & $\begin{array}{r}76 \\
272 \\
81 \\
185\end{array}$ & $\begin{array}{l}93 \cdot 8 \\
76 \\
81 \\
92 \cdot 5\end{array}$ & & & $\begin{array}{r}23 \\
5\end{array}$ & $0^{0} \begin{array}{l}6 \cdot 4 \\
5\end{array}$ & $\begin{array}{r}5 \\
63 \\
14 \\
15\end{array}$ & $\begin{array}{c}6 \cdot 2 \\
17 \cdot 6 \\
14 \\
7 \cdot 5\end{array}$ \\
\hline $\begin{array}{l}\text { Case } 2 \\
\text { Lymphocytes } \\
\text { Newborn } \\
1 \text { year } \\
12 \text { years } \\
16 \text { years }\end{array}$ & $\begin{array}{l}100 \\
100 \\
180 \\
100\end{array}$ & $\begin{array}{r}27 \\
175 \\
99\end{array}$ & $\begin{array}{l}0 \\
27 \\
97 \cdot 2 \\
99\end{array}$ & & & $\begin{array}{r}10 \\
54 \\
5 \\
1\end{array}$ & $\begin{array}{c}10 \\
54 \\
2 \cdot 8 \\
1\end{array}$ & & & $\begin{array}{l}90 \\
19\end{array}$ & $\begin{array}{l}90 \\
19 \\
0 \\
0\end{array}$ \\
\hline $\begin{array}{c}\text { Fibroblasts } \\
\text { Newborn } \\
14 \text { years }\end{array}$ & $\begin{array}{l}54 \\
50\end{array}$ & & $\begin{array}{l}0 \\
0\end{array}$ & & & $\begin{array}{l}53 \\
50\end{array}$ & $\begin{array}{l}98 \cdot 1 \\
100\end{array}$ & & & 1 & $0^{1.9}$ \\
\hline
\end{tabular}

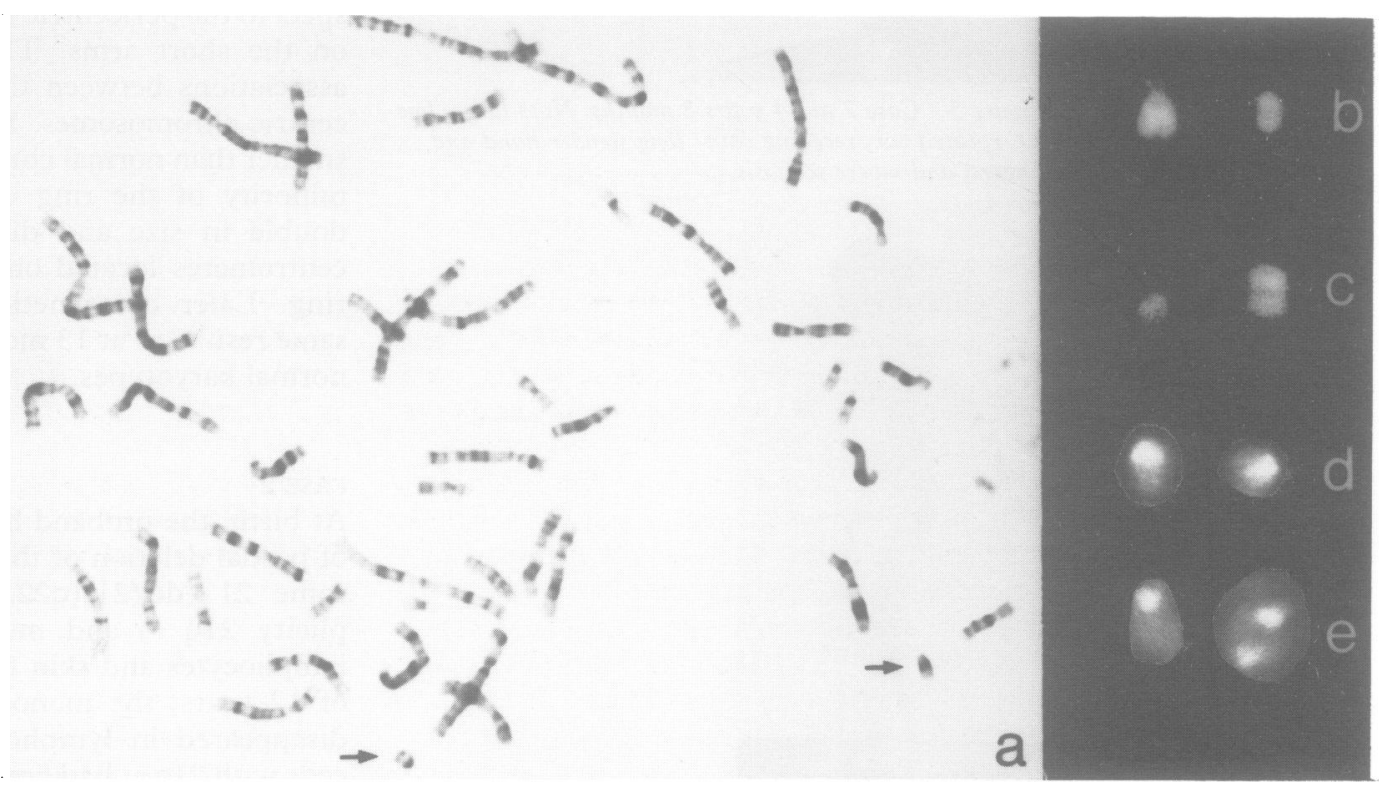

Figure 9 Case 1. (a) GTG banded metaphase with 46,r(21) karyotype, with arrows indicating the ring chromosome 21 (left) and the normal chromosome 21 (right); (b-e) partial karyotypes from four metaphases of normal chromosome 21 (left) and ring chromosome 21 (right): (b) $Q F Q$ banding, single ring; (c) $Q F Q$ banding, double sized $r(21)$; (d) FISH with chromosome 21/13 alphoid DNA probe, single ring; (e) FISH as (d), double sized $r(21)$. Note in $(e)$ the two alphoid regions which are located on opposite sides of the ring chromosome.

locus to the centromere was D21S215 and the closest locus to the telomere of the long arm was COL6A1). The findings indicated the presence of two identical chromosomes 21 from the father (uniparental disomy). The $46, r(21)$ cells were studied using cultured fibroblasts taken at 1 month and four different DNA polymorphisms spanning the interval D21S215 to D21S112. The most distal locus studied (D21S112) was not deleted, which places the breakpoint on 21q between D21S112 and the 21q telomere.

CASE 2

The 46,XX cells were studied using blood taken at 12 years and the 17 DNA polymor- phisms described in case 1. Maternal isodisomy was found for the chromosome 21 long arm. The $21 \mathrm{q}-$ cells were examined using cultured fibroblasts taken at 14 years and 16 different polymorphisms spanning the interval D21S215 to D21S112. A paternal origin of the $21 \mathrm{q}$ - chromosome was found. The loci from D21S82 to D21S112 were deleted, confirming the cytogenetic findings.

\section{Discussion}

To date, the 46,r(21) karyotype has been reported in more than 70 persons. Roughly three quarters of the cases of $46, r(21)$ had a normal phenotype or the mild phenotype described by Gardner et al. ${ }^{5}$ These persons must 
Table 2 Clinical features of different chromosome 21 deletion syndromes and cases 1 and 2

\begin{tabular}{|c|c|c|c|c|c|c|c|}
\hline \multirow[t]{2}{*}{ Characteristics } & \multicolumn{2}{|c|}{$\begin{array}{l}\text { Cases of partial } \\
\text { monosomy } 21\end{array}$} & \multirow{2}{*}{$\begin{array}{l}\text { Single case } \\
\text { of deletion } \\
21 q 11 \rightarrow q 21^{12}\end{array}$} & \multirow{2}{*}{$\begin{array}{l}\text { Single case } \\
\text { of deletion } \\
21 q 22.1 \text { or } .2 \rightarrow \text { qter }^{13}\end{array}$} & \multirow[t]{2}{*}{$\begin{array}{l}\text { Seven cases of } \\
r(21)(p 1 ; q 22.3)^{8 *}\end{array}$} & \multirow{2}{*}{$\begin{array}{l}\text { Case } 1: \\
r(21)(p 1 ; q 22.3) \\
\text { and monosomy } 21\end{array}$} & \multirow{2}{*}{$\begin{array}{l}\text { Case } 2 \text { : } \\
\text { deletion } 21 q 22.1 \rightarrow q t e r \\
\text { and monosomy } 21\end{array}$} \\
\hline & $\begin{array}{l}\text { Warren } \\
\text { et al }\end{array}$ & $\begin{array}{l}\text { Krasikov } \\
\text { et al }{ }^{11}\end{array}$ & & & & & \\
\hline $\begin{array}{l}\text { Nervous system } \\
\text { Development delay/MR } \\
\text { Abnormal tone, increased } \\
\text { Microcephaly } \\
\text { CNS abnormality } \\
\text { Seizures }\end{array}$ & $\begin{array}{l}5 / 5 \\
5 / 5 \\
5 / 5\end{array}$ & $\begin{array}{l}6 / 6 \\
5 / 10 \\
2 / 5 \\
5 / 5 \\
5 / 5\end{array}$ & $\begin{array}{l}- \\
+ \\
+ \\
+\end{array}$ & $\begin{array}{l}+ \\
+ \\
+\end{array}$ & $\begin{array}{l}- \\
- \\
- \\
-\end{array}$ & $\begin{array}{l}+ \\
+ \\
+ \\
+ \\
+\end{array}$ & $\begin{array}{l}+ \\
+ \\
+ \\
- \\
-\end{array}$ \\
\hline $\begin{array}{l}\text { Face } \\
\text { Downward slanting eyes } \\
\text { Microphthalmia } \\
\text { Large, low set, rotated ears } \\
\text { Ears malformed (large lobes) } \\
\text { Preauricular fistulas } \\
\text { Hypertelorism/telecanthus } \\
\text { Prominent nasal bridge } \\
\text { Broad base of nose } \\
\text { Downward slanting mouth } \\
\text { Thin vermilion } \\
\text { Cleft lip/palate } \\
\text { High arched palate } \\
\text { Micro/retrognathia }\end{array}$ & $\begin{array}{l}6 / 6 \\
5 / 5 \\
5 / 5 \\
2 / 3 \\
3 / 4 \\
6 / 6\end{array}$ & $\begin{array}{c}9 / 9 \\
13 / 13 \\
13 / 13 \\
9 / 10 \\
10 / 10 \\
6 / 7 \\
3 / 3 \\
13 / 13\end{array}$ & $\begin{array}{l}+ \\
- \\
+ \\
+ \\
- \\
- \\
+ \\
+ \\
- \\
- \\
+ \\
-\end{array}$ & $\begin{array}{l}+ \\
+ \\
+ \\
+\end{array}$ & $\begin{array}{l}\overline{-} \\
\overline{-} \\
\overline{-} \\
\overline{-} \\
\overline{-} \\
\overline{-} \\
\overline{-} \\
\overline{-} \\
\overline{-}\end{array}$ & $\begin{array}{l}+ \\
- \\
+ \\
+ \\
- \\
+ \\
+ \\
+ \\
- \\
+ \\
+ \\
+\end{array}$ & $\begin{array}{l}+ \\
- \\
+ \\
+ \\
- \\
+ \\
+ \\
+ \\
+ \\
- \\
+ \\
+ \\
+\end{array}$ \\
\hline $\begin{array}{l}\text { Skeleton } \\
\text { Intrauterine growth retardation } \\
\text { Postnatal growth retardation } \\
\text { Short neck } \\
\text { Minor skeletal anomalies } \\
\text { Flexion deformity, malposition of } \\
\text { finger/toes }\end{array}$ & $\begin{array}{l}5 / 5 \\
5 / 5 \\
5 / 5\end{array}$ & $\begin{array}{l}7 / 10 \\
4 / 4 \\
7 / 8 \\
6 / 11 \\
12 / 12\end{array}$ & - & $\begin{array}{l}+ \\
+\end{array}$ & $\begin{array}{l}- \\
- \\
- \\
-\end{array}$ & $\begin{array}{l}+ \\
+ \\
+ \\
+ \\
+\end{array}$ & $\begin{array}{l}+ \\
+ \\
+ \\
+ \\
+\end{array}$ \\
\hline $\begin{array}{l}\text { Other } \\
\text { Congenital heart disorder } \\
\text { Renal agenesis/cysts } \\
\text { Imperforate/anterior anus } \\
\text { Thrombocytopenia }\end{array}$ & $3 / 4$ & $\begin{array}{l}7 / 10 \\
4 / 9 \\
3 / 3\end{array}$ & - & & - & $\begin{array}{l}- \\
- \\
\overline{+}\end{array}$ & $\begin{array}{l}- \\
- \\
- \\
-\end{array}$ \\
\hline
\end{tabular}

* Cases $1 \mathrm{~A}, 1 \mathrm{~B}, 2 \mathrm{~A}, 2 \mathrm{~B}, 3,4$, and 5 .

have lost little or no genetically relevant chromosomal material during the ring formation. About a quarter of the cases of $46, \mathrm{r}(21)$ and case 1 presented with the classic severe $r(21)$ phenotype. ${ }^{6}$ This phenotype can practically be equated with the monosomy 21 syndrome. ${ }^{57}$

Twelve cases of $r(21)$ have been analysed with molecular techniques. ${ }^{89}$ In nine of these cases and in case 1 the $r(21)$ was most likely formed by breakage and reunion of the short and long arms of a chromosome 21 . In case 1 the breakpoint on $21 \mathrm{q}$ was located between D21S112 and the telomere of 21q. This indicates a deletion of less than $1.8 \mathrm{Mb}$ from chromosomal band q22.3, and of less than $1 / 20$ of the total DNA from $21 \mathrm{q} .{ }^{10}$ The definition of the breakpoint on $21 \mathrm{p}$ is of lesser importance because the short arm of chromosome 21 contains no functional genes and $21 \mathrm{p}$ deletions do not affect the phenotype. The absence of satellite associations between the ring and the acrocentric chromosomes suggests a breakpoint location within $21 \mathrm{p} 11 \rightarrow \mathrm{p} 12$.

A comparison with other published reports (table 2) showed no correlation between the severe phenotype of case 1 and the small deletion from $21 \mathrm{q}$. Seven persons from five families with 46,r(21) karyotypes and almost identical breakpoints (as determined by molecular techniques) have been described; these persons had near normal phenotypes. ${ }^{8}$ They had significantly fewer monosomic cells (less than $4 \%$ ) than case 1 (more than $50 \%$ before the development of the $46, \mathrm{XX}$ cells).

Some clinical features of case 1 have recently been linked to proximal deletions of 21q. Arthrogryposis, muscular hypertonia, and mental retardation were associated with deletion of $21 \mathrm{q} 11 \rightarrow \mathrm{q} 21$ (a segment of roughly $13 \mathrm{Mb}$ from proximal 21q). ${ }^{14}$ In a single case study, deletion of $21 \mathrm{q} 11 \rightarrow \mathrm{q} 21.2$ was linked to downward slanting palpebral fissures and mouth, large ears, muscular hypertonia, skeletal anomalies, and normal intelligence. ${ }^{12}$ On the molecular level, the severe mental retardation with the monosomy 21 phenotype was associated with a deletion between loci D21S17 and D21S44. ${ }^{15}$ Case 1 has a number of these features (muscular hypertonia, severe mental retardation, downward slanting palpebral fissures, large ears) although her deletion is outside these critical regions.

From these data it seems most likely that in case 1 the phenotype was determined by the monosomic cells. It is of interest here that the lymphocyte cultures from case 1 contained more cells with monosomy 21 than with $r(21)$ (table 1). This can result from frequent mitotic losses of the ring and from clonal growth of the monosomy 21 cells (true chromosomal mosaicism).

With respect to the phenotype and the extent of the cytogenetic deletion, case 2 shares similarities with a case reported in 1979 by Yamamoto et al. ${ }^{13}$ Features present in both cases included intrauterine growth failure, developmental delay, increased muscle tone, microcephaly, short neck, and flexion deformities. In addition, that child had microphthalmia, preauricular pits, and severe micrognathia, that is, morphogenetic defects of the first and second branchial arches. ${ }^{13}$ Branchial arch defects (facial asymmetry, macrostomia, small ears, preauricular skin tags) were also present in two other cases. ${ }^{8}$ The gene(s) responsible were tentatively located between loci HMG14 and D21S112 on distal 21q. ${ }^{8}$ The molecular assignment agrees with the absence 
of branchial arch anomalies in case 1 and their presence (facial asymmetry, microtia) in case 2.

We can postulate for both cases described here that during fetal development, all the cells (for example, neurones) had an abnormal karyotype. With the isodisomic cells being present only in lymphocytes, an improvement of the clinical course as the result of isodisomy could not be expected. The rapid change of karyotype in the blood indicates that the isodisomy provided a selective advantage for the lymphocyte population with the normal karyotype. Persons with $r(21)$ are at high risk for leukaemic disorders. ${ }^{16-19}$ The compensatory isodisomy might reduce this risk.

The two cases illustrate a new mechanism leading to uniparental disomy, ${ }^{1}$ and they show that this new mechanism has the potential to result in false normal cytogenetic findings. This underlines that karyotyping using fibroblasts must be recommended in cases with a phenotype of a chromosome aberration and a normal karyotype from blood.

The incidence of compensatory isodisomy is not known. We know of one case where compensatory isodisomy might possibly be suspected, with karyotypes of $46, \mathrm{XX} / 45, \mathrm{XX},-21$ in blood and $46, \mathrm{XX},-21,+\mathrm{r}(21)$ in skin. ${ }^{20}$

1 Petersen MB, Bartsch O, Adelsberger PA, Mikkelsen M, Schwinger E, Antonarakis SE. Uniparental isodisomy due to duplication of chromosome 21 occurring in somatic due to duplication of chromosome 21 occurring in somatic cells monosomic

2 Mikkelsen $M$, Vestermark S. Karyotype 45,XX,-21/ $46, X X, 21 q^{-}$in an infant with symptoms of $G$ deletion syndrome I. 7 Med Genet 1974;11:389-93.

3 Bartsch O, Schwinger E. A simplified protocol for fluorescence in situ hybridization with repetitive DNA probes and its use in clinical cytogenetics. Clin Genet 1991;40:47-

4 Devilee P, Slagboom P, Cornelisse CJ, Pearson PL. Se- quence heterogeneity within the human alphoid repetitive DNA family. Nucleic Acids Res 1986;14:2059-74

5 Gardner RJM, Monk NA, Clarkson JE, Allen GJ. Ring 21 chromosome: the mild end of the phenotypic spectrum Clin Genet 1986;30:466-70.

6 Richer CL, Fitch N, Sitahal S, Murer-Orlando M, Pierre J. Analysis of banding patterns in a case of ring chromosome 21. Am f Med Genet 1981;10:323-31.

7 Warren RJ, Rimoin DL. The G deletion syndromes. Pediatrics 1970;77:658-63

8 McGinniss MJ, Kazazian HH, Stetten G, et al. Mechanisms of ring chromosome formation in 11 cases of human ring chromosome 21. Am ₹ Hum Genet 1992;50:15-28.

9 Wong C, Kazazian HH, Stetten G, Earnshaw C, Van Keuren ML, Antonarakis SE. Molecular mechanism in the formation of a human ring chromosome 21. Proc Natl Acad Sci USA 1989;86:1914-8.

10 Burmeister M, Kim S, Price ER, et al. A map of the distal region of the long arm of human chromosome 21 constructed by radiation hybrid mapping and pulsed-field gel electrophoresis. Genomics 1991;9:19-30.

11 Krasikov N, Takaesu N, Hassold T, Knops JF, Finley WH Scarbrough P. Molecular and cytogenetic investigation of complex tissue-specific duplication and loss of chromosome 21 in a child with a monosomy 21 phenotype. $A m \mathcal{F}$ Med Genet 1992;43:554-60.

12 Korenberg JR, Kalousek DK, Anneren G, et al. Deletion of chromosome 21 and normal intelligence: molecular definition of the lesion. Hum Genet 1991;87:112-8.

13 Yamamoto Y, Ogasawara N, Gotoh A, Komiya H, Nakai H Kuroki Y. A case of $21 \mathrm{q}-$ syndrome with normal SOD - 1 Kuroki Y. A case of 21q- syndrom

14 Chettouh Z, Sinet PM, Teboul, et al. Hypertonia, arthrogryposis and mental retardation associated with a deletion of posis and mental retardation associated with a deletion of the centromere-D21S1 region on chromosome 21 .

15 Korenberg JR, Falik-Borenstein TC, Muenke M, Mennuti MC, Pulst SM. Partial monosomies of chromosome 21 and mental retardation: molecular definition of the region. Am f Hum Genet (Suppl) 1990;47:A31.

16 Falchi AM, Orofino MG, Nucaro AL, De Virgiliis S, Cao A. Acute lymphoblastic leukemia in a child with constitutional ring chromosome 21. Cancer Genet Cytogenet 1987;27:219-24

17 Pui CH, Williams DL, Scarborough V, Jackson CW, Price R, Murphy S. Acute megaloblastic leukemia associated with intrinsic platelet dysfunction and constitutional ring 21 chromosome in a young boy. $\mathrm{Br} f$ Haematol 1982;50:191-200.

18 Cabrol C, Werner-Favre C, Wyss M, Pitmon D, Engel E. Acute lymphoblastic leukemia in two children with a congenital chromosome anomaly: familial inv(11)(p15q13) in one and ring chromosome no. 21 in the other. Cancer Genet Cytogenet 1983;8:67-74.

19 Dalgleish R, Duckett DP, Woodhouse M, Shannon RS Young ID. Apparent monosomy 21 owing to a ring 21 Young ID. Apparent monosomy 21 owing to a ring 21 chromosome: parental origin
Med Genet 1988;25:851-4.

20 Richmond HG, MacArthur P, Hunter D. A 'G' deletion syndrome: anti-mongolism. Acta Paediatr Scand 1973;62:216-20. 